\title{
The Factors That Influence Foreign Holdings of Malaysian Government Bonds
}

\section{Zaidey Evon, Hock-Ann Lee}

To Link this Article: http://dx.doi.org/10.6007/IJARBSS/v11-i12/11711

DOI:10.6007/IJARBSS/v11-i12/11711

Received: 23 October 2021, Revised: 27 November 2021, Accepted: 10 December 2021

Published Online: 24 December 2021

In-Text Citation: (Evon \& Lee, 2021)

To Cite this Article: Evon, Z., \& Lee, H.-A. (2021). The Factors That Influence Foreign Holdings of Malaysian Government Bonds. International Journal of Academic Research in Business and Social Sciences, 11(12), 1874-1890.

\section{Copyright: (c) 2021 The Author(s)}

Published by Human Resource Management Academic Research Society (www.hrmars.com)

This article is published under the Creative Commons Attribution (CC BY 4.0) license. Anyone may reproduce, distribute, translate and create derivative works of this article (for both commercial and non0-commercial purposes), subject to full attribution to the original publication and authors. The full terms of this license may be seen at: http://creativecommons.org/licences/by/4.0/legalcode

Vol. 11, No. 12, 2021, Pg. $1874-1890$

Full Terms \& Conditions of access and use can be found at http://hrmars.com/index.php/pages/detail/publication-ethics 


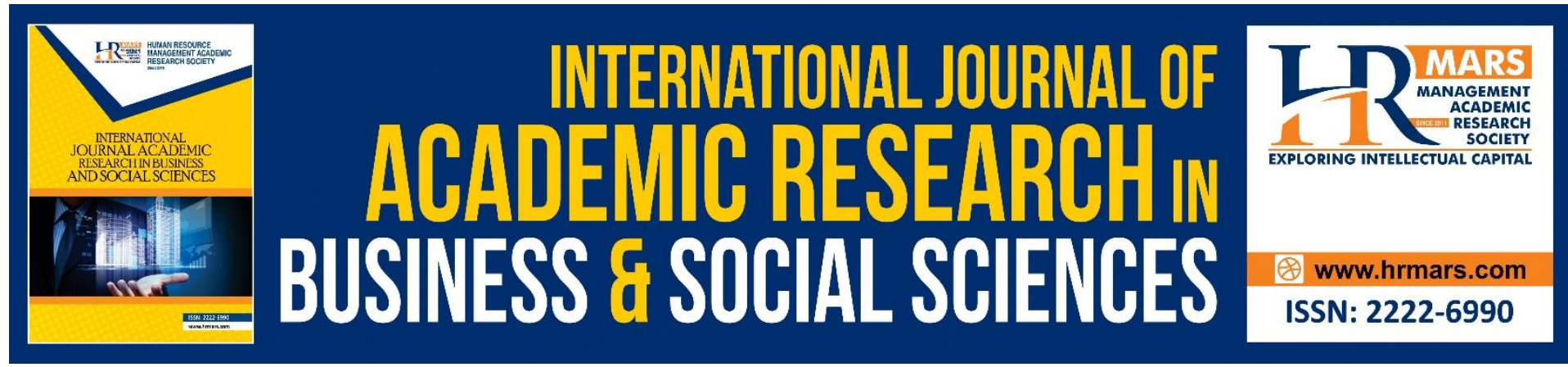

\title{
The Factors That Influence Foreign Holdings of Malaysian Government Bonds
}

\author{
Zaidey Evon, Hock-Ann Lee \\ Labuan Faculty of International Finance, Universiti Malaysia Sabah, Jalan Sungai Pagar, \\ 87000 W.P. Labuan, Malaysia \\ Email: hockann@ums.edu.my
}

\begin{abstract}
While the flows of global capital can facilitate optimal global monetary allocation, they can also cause global macroeconomic imbalances before and after financial crises. From this point of view, looking into what causes the flows of capital is important to prevent economic turmoil and financial crises. Therefore, this research aims to examine the impact of pull factors (domestic factors) and push factors (US unconventional monetary policy) on the foreign bondholding in Malaysia. This research analyses monthly data for the period January 2008 - April 2018 using the Autoregressive Distributed Lag (ARDL) method. The empirical results reveal that the empirical model with US total assets is the best model in investigating the impact of all the independent variables toward the foreign bondholding in Malaysia. According to the findings of this research, each of the pull variables has a significant long-run relationship with foreign bondholding in Malaysia. Most crucially, total asset, an unconventional monetary policy tool used by the United States, has a significant positive link with foreign bondholding in Malaysia. Despite these promising findings, further research should be conducted to investigate the disaggregated analysis of US total assets on the foreign bondholding of Malaysian government bonds.
\end{abstract}

Keywords: Foreign Bondholding, Unconventional Monetary Policy, US Balance Sheet

\section{Introduction}

The financial crisis in United States of America (US) started in year 2007 due to the US subprime mortgage crisis before having its full effect in year 2008 which saw the collapsed of Lehman Brothers. Since then, US has to resort in implementing unconventional monetary policy during the period of the financial crisis to reverse the economic downturns. Unconventional monetary policy involves the purchasing of assets by Central Bank which in US is the Federal Reserve (Bhattarai \& Neely, 2016). This unconventional monetary policy is conducted to influence the long-term interest rates where the conventional monetary tool of US which is the US Federal fund rate has reached zero bound level (Bhattarai \& Neely, 2016). Hence, the ongoing discussion among researchers on the effect of this policy provide room for further exploration especially on its direct impact to emerging market like Malaysia.

As illustrated in Figure 1, the sovereign bond spreads of ASEAN 5, which includes Malaysia, are the highest in comparison to China, Australia, and the Republic of Korea as of 
March 2015. This high spread signifies that during the period of the US unconventional monetary policy, ASEAN 5 region has provided an attractive bond spreads to investors. And further illustrated in Figure 2, the high spread has caused Malaysia to be one of the most attractive markets for non-residents investors to purchase government bonds. Hence, based on both of these figures it is imperative to investigate the factors which contribute to the steady increase of foreign bondholding in Malaysia since the US financial crisis in year 2008.

Generally, the research objective is to investigate the relationship between the foreign bondholding in Malaysia with Malaysia price level, Malaysia industrial production index, Malaysia trade balance, Malaysia 10-year maturity rate of Malaysian Government Securities, US total assets and US Federal fund rate. Specifically, the main objectives are to (1) investigate the impact of domestic factors on Malaysian foreign bondholding and (2) investigate the impact of US unconventional monetary policies on Malaysian foreign bondholding..

Additionally, a quarterly bulletin released by Bank Negara Malaysia (BNM) in the second quarter of 2017 revealed that Malaysia ranks second behind Indonesia in terms of foreign bondholding among Asian countries such as Indonesia, Thailand, Korea, and Japan (Abdullah \& Razali, 2017). The report also revealed the high share of foreign bondholding in Malaysia is influenced by several domestic factors particularly involving economic fundamentals. Besides, it is also reported where towards the end of year 2016, the foreign bondholding in Malaysia has fell following the US presidential result. Based on the abovementioned report, it is clear that not only pull factors (domestic factors) that can influence the foreign bondholding in Malaysia but also the push factors. As previous studies on the issue have employed large-scale asset purchase programmes (LSAPs) announcements and US long-term yields to represent the US unconventional monetary policy (Fratzscher et al., 2018; Moore et al., 2013; Tillmann, 2016). Therefore, this study is trying to present a new perspective by looking at the direct impact of the US unconventional monetary policy by employing the total assets of the Federal Reserve balance sheets and representation part of the federal fund rate using $\mathrm{Wu}$ and Xia (2016) shadow rate towards the foreign bondholding in Malaysia.

The following is the structure of this research. The literature on the push and pull frameworks in capital flows is reviewed in Section 2. The study's empirical model and estimation procedures are discussed in Section 3. The study's main findings will be presented in Section 4. The study's discussion and conclusion are presented in Section 5. 
Figure 1: Ten-Year Sovereign Bond Spreads over the US (\%)

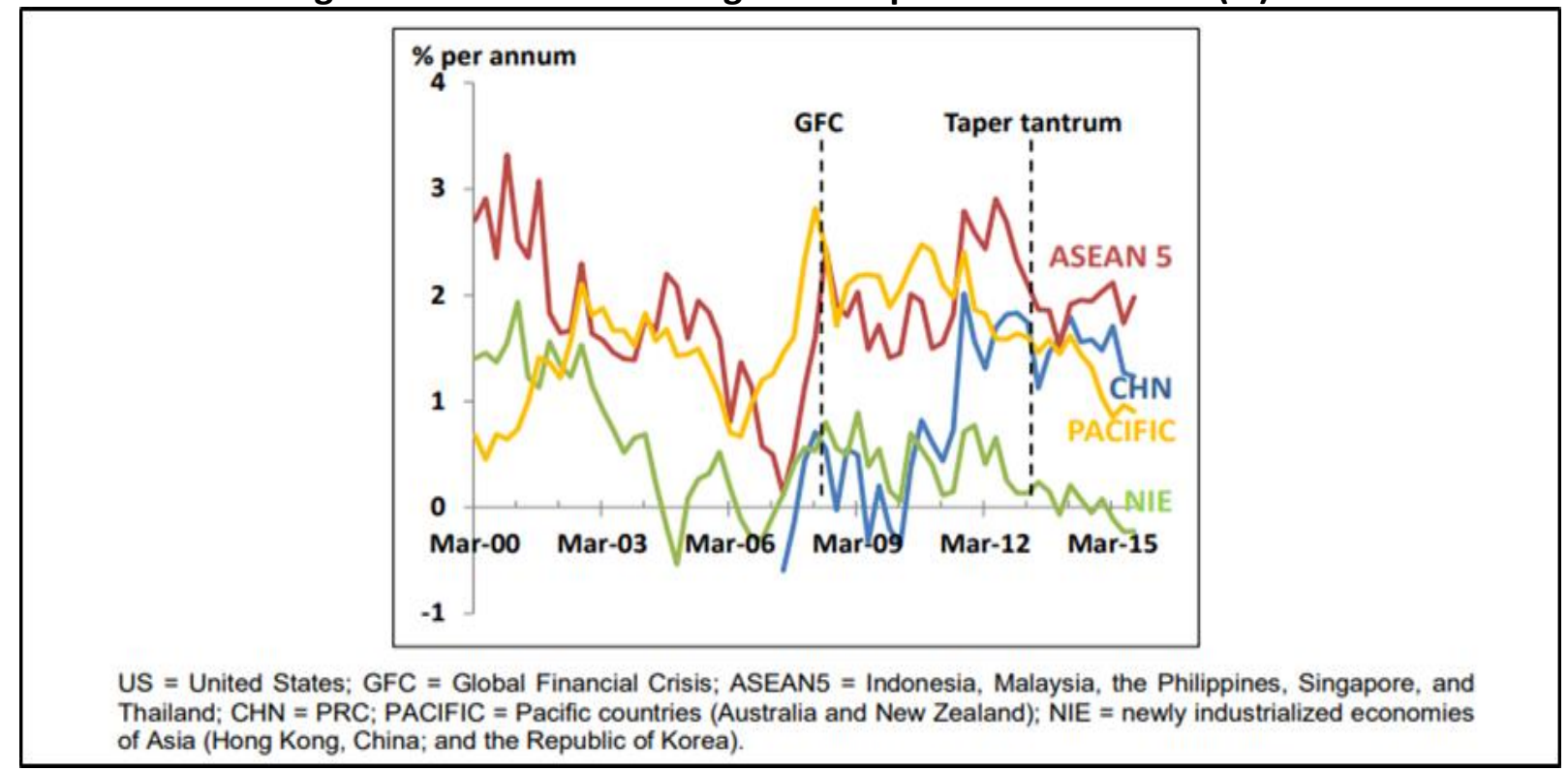

Source: Punzi and Chantapacdepong, (2017)

Figure 2: Net Bond Flows

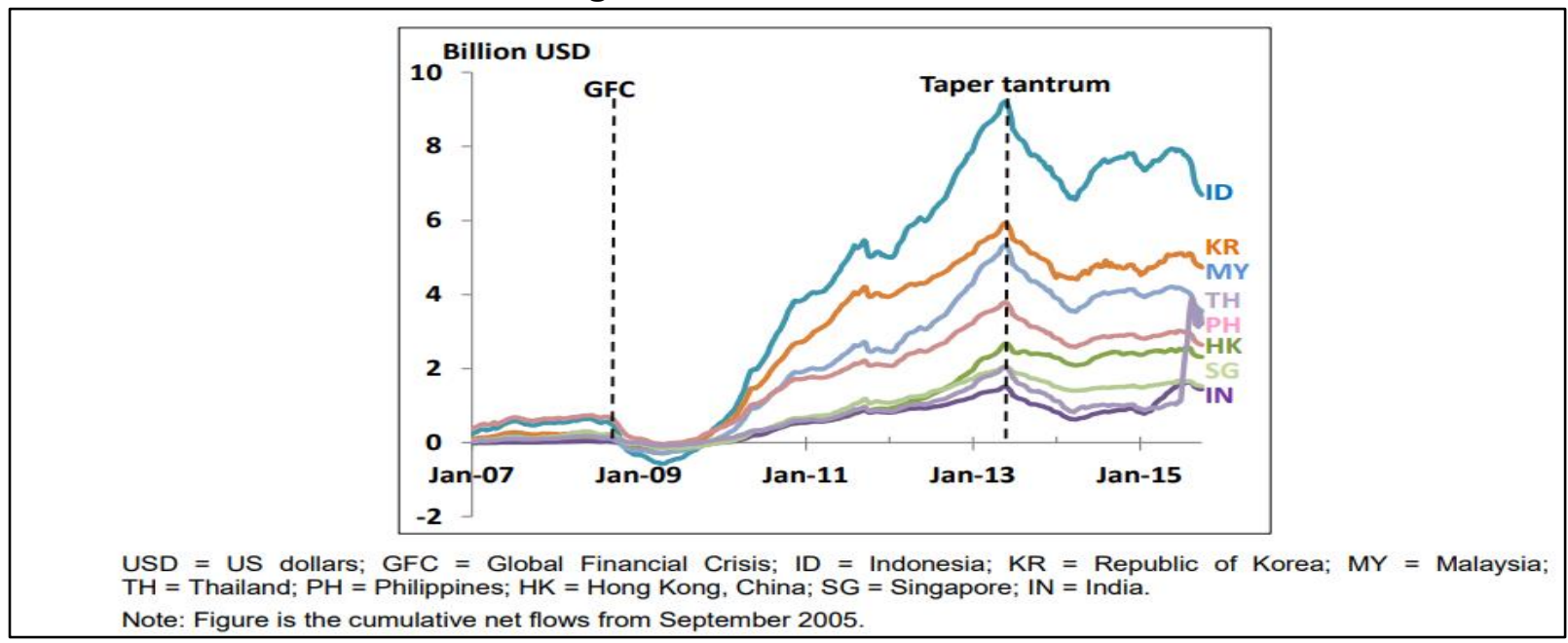

Source: Punzi and Chantapacdepong, (2017)

\section{Literature Review}

Several studies have been conducted on this topic, including one by Burger, Sengupta, Warnock and Warnock (2015), who used panel data approaches to investigate the factors that influenced the allocation of US investors' international bonds for the period 2006-2011. The results of the study indicate that during the US financial crisis period, US investors have increased their local currency bond allocation towards emerging market economies and this allocation accelerated further post the US financial crisis. The contributing factors which led to this allocation are due to the strong macroeconomic fundamentals of the emerging market economies with higher bond yields, stable inflation and more positive account balance. In terms of the push factors, the result of the study also reveals that low level of US Treasury yields effectively the US Federal fund rate and also the implementation of the US unconventional monetary policy have also contributed to the increase of bondholding by US investors in emerging market economies. 
Another study by Fratzscher (2012), employed the factor model approach to investigate the pull and push factors which may have contributed to the global capital flows over the period of 2005 until 2010. There is evidence to suggest that push factors have a significant impact on global capital flows to emerging market economies during the US financial crisis. Push factors which contributed to this finding were shocks to liquidity and risk and also the macroeconomic policies implemented by advanced economies like US. The study also highlights that during the post US financial crisis, pull factors such as having good macroeconomic fundamentals and institutions have exerted a significant impact in driving global capital flows. While study by Kiendrebeogo (2016) finds that strong macroeconomic fundamentals such as better flexibility in exchange rate, strong current account and fiscal positions and also higher capital mobility will be able to mitigate the effect of a reversal in the US unconventional monetary policy.

In a study by Cerutti, Claessens and Puy (2017), the study employed a systematic analysis of 34 emerging market economies over the period of 2001 until 2013. The result of the study argued that a country's macroeconomic fundamentals possess influence towards the level of capital flow into the country especially bond purchase by non-residents in particular the variable of commodities price. However, the study argued that push factors possess higher explanatory power than pull factors. Koepke (2018), in a recent study that used panel data approaches and monthly data, found that capital flows into emerging market economies, particularly bond flows, are heavily influenced by both push and pull factors. The study argued that non-residents purchases of emerging market economies' securities in particular bond flows are significantly impacted by US monetary policy expectation and VIX (volatility index). The bond flows of emerging market economies are also significantly impacted by pull factors such as emerging market stock market index and EM bond yield spread over US Treasuries.

Overall, through the aforementioned studies it is clear that most of the studies that have been conducted argued that there is a need to look at both pull and push factors that could influence the global capital flows into emerging market economies like Malaysia. Based on the aforementioned studies also, with respect to this study, it is evident that both pull factors in Malaysia and also push factors primarily focusing on US unconventional monetary policy need to be taken into account to investigate their impact on the foreign bondholding in Malaysia. Furthermore, the lack of studies directly assessing how the US monetary policy during the financial crisis affected foreign bondholding in Malaysia make this research even more pertinent with regards to this ongoing discussion of the US unconventional monetary policy.

\section{Methodology}

\section{Data Sources}

A total of 124 observations, spanning the months of January 2008 through April 2018, are used in this study. The majority of the data comes from Bank Negara Malaysia reports, specifically for domestic variables such as foreign bondholding in Malaysia (InFHOMGS), industrial production index (InIPI), trade balance (InTB), and 10-year maturity rate of Malaysian Government Securities (MY10), while the IMF's International Financial Statistics is used for the Malaysia price level (InCPI). External variables such as US total assets (InUSTA) and the US Federal funds rate (USFS) are sourced from the Federal Reserve Bank of St. Louis. In terms of the USFS, this research uses the shadow rate from Wu and Xia (2016) to represent the federal funds rate for the period January 2009 - November 2015. From January to 
December 2008, and again from December 2015 onwards, the Federal Reserve Bank of St. Louis's federal fund rate data is used.

\section{Empirical Model}

The baseline model is used in conjunction with a function developed by Eichler and Plaga (2017) that uses bondholding as the dependent variable. It should be noted that in this study the bondholding will be represented by foreign ownership of Malaysian Govenrment Securities. The non-linear equation of the model is as follow:

FHOMGS $_{\mathrm{t}}=\exp \left(X_{i, t} \beta+\alpha_{\mathrm{t}}+\mu_{\mathrm{i}}\right)+\varepsilon_{\mathrm{i}, \mathrm{t}}$

where FHOMGS is Malaysia's foreign bondholding, as explained by a collection of macroeconomic and financial factors contained in $\mathrm{X}$.

The model is then extended to investigate the long-run effect of Malaysia's price level (InCPI), industrial production index (InIPI), trade balance (InTB), 10-year maturity rate of Malaysian Government Securities (MY10), US total assets (InUSTA), and US Federal fund rate (USFS) on Malaysia's foreign bondholding (InFHOMGS). As a result, Pesaran, Shin, and Smith (2001) used the Autoregressive Distributed Lag (ARDL) to examine the long-run relationship between the variables. The ARDL technique is used in this research because it has various advantages, including the ability to estimate models for both the long and short runs at the same time, as well as the ability to correct endogeneity in explanatory variables.

Further, the model is separated into two to investigate which US unconventional monetary policy tools has the biggest impact in influencing the level of foreign bondholding in Malaysia.

US total assets as one of the independent variables:

$\Delta \operatorname{lnFHOMGS}=\beta_{0}+\sum \beta_{1} \Delta \ln$ FHOMGS $_{t-i}+\sum \beta_{2} \Delta \ln C P I_{t-i}+\sum \beta_{3} \Delta \ln I P I_{t-i}+$ $\sum \beta_{4} \Delta \ln T B_{t-i}+\sum \beta_{5} \Delta M Y 10_{t-i}+\sum \beta_{6} \Delta \ln U S T A_{t-i}+\alpha_{1} \ln F H O M G S_{t-1}+$ $\alpha_{2} \ln C P I_{t-1}+\alpha_{3} \ln I P I_{t-1}+\alpha_{4} \ln T B_{t-1}+\alpha_{5} M Y 10_{t-1}+\alpha_{6} \ln U S T A_{t-1}+\mu_{t}$

US Federal fund rate as one of the independent variables:

$\Delta \operatorname{lnFHOMGS}=\beta_{0}+\sum \beta_{1} \Delta \ln$ FHOMGS $_{t-i}+\sum \beta_{2} \Delta \ln C P I_{t-i}+\sum \beta_{3} \Delta \ln I P I_{t-i}+$ $\sum \beta_{4} \Delta \ln T B_{t-i}+\sum \beta_{5} \Delta M Y 10_{t-i}+\sum \beta_{6} \Delta U S F S_{t-i}+\alpha_{1} \ln F H O M G S_{t-1}+\alpha_{2} \ln C P I_{t-1}+$ $\alpha_{3}{\ln I P I_{t-1}}+\alpha_{4} \ln T B_{t-1}+\alpha_{5} M Y 10_{t-1}+\alpha_{6} U S F S_{t-1}+\mu_{t}$

(3)

where $\beta_{0}$ is the drift component, $\ln C P I_{t}$ is the natural log of the consumer price index which is the proxy for Malaysia inflation level, $\ln I P I_{t}$ is the natural log of Malaysia industrial production index, $\ln T B_{t}$ is the natural log of Malaysia trade balance, $\ln U S T A_{t}$ is the natural log of US total assets, and $\mu_{t}$ is the error term.

The models are examined using the bound test approach developed by Pesaran et al. (2001) to see if there is a long term relationship between all of the variables. F tests were used to examine the coefficients of joint significance of lagged level variables using the following hypotheses:

$\mathrm{H}_{0}: \alpha_{1}=\alpha_{2}=\alpha_{3}=\alpha_{4}=\alpha_{5}=\alpha_{6}$

$\mathrm{H}_{1}: \alpha_{1} \neq \alpha_{2} \neq \alpha_{3} \neq \alpha_{4} \neq \alpha_{5} \neq \alpha_{6}$ 
According to Pesaran et al (2001), the bound test approach will have two sets of critical values which are the lower critical bound $I(0)$, and the upper bound $/(1)$. If the generated Fstatistics is more than the upper bound then cointegration exists, where the null hypothesis will be rejected. Lastly, if both models have cointegration then the models will be expanded under the error correction model (ECM) as follows:

$\Delta \operatorname{lnFHOMGS}=\beta_{0}+\sum \beta_{1} \Delta \ln$ FHOMGS $_{t-i}+\sum \beta_{2} \Delta \ln C P I_{t-i}+\sum \beta_{3} \Delta \ln I P I_{t-i}+$ $\sum \beta_{4} \Delta \ln T B_{t-i}+\sum \beta_{5} \Delta M Y 10_{t-i}+\sum \beta_{6} \Delta \ln U S T A_{t-i}+\lambda E C_{t-1}+\mu_{t}$

$\Delta \operatorname{lnFHOMGS}=\beta_{0}+\sum \beta_{1} \Delta \ln F H O M G S_{t-i}+\sum \beta_{2} \Delta \ln C P I_{t-i}+\sum \beta_{3} \Delta \ln I P I_{t-i}+$ $\sum \beta_{4} \Delta \ln T B_{t-i}+\sum \beta_{5} \Delta M Y 10_{t-i}+\sum \beta_{6} \Delta U S F S+\lambda E C_{t-1}+\mu_{t}$

where $\lambda$ is the adjustment parameter speed and EC is the residuals generated from equation (2) and (3).

\section{Empirical Results \\ Descriptive Statistics}

Based on Figure 3, for Foreign Bondholding in Malaysia (InFHOMGS) from mid-year 2009 until around mid-year 2012, the trend of the foreign bondholding in Malaysia show an increasing trend, which shows that the amount of bondholding by foreigners were steadily increasing the during the period. During this period, the Malaysia price level (InCPI) and industrial production index (InIPI) were in constant trend, whereas Malaysia trade balance (InTB) and 10 -year maturity rate of Malaysia Government Securities exhibit a volatile trend. Since the commencement of the US financial crisis in 2008, foreign bond holdings had been dropping until the second quarter of 2009, when they began to rise again due to the reversal of funds back to the US (Bank Negara Malaysia, 2009). During the period from year 2008 to 2018, the foreign bondholding in Malaysia reached its lowest point during March, 2009 at $8.89 \%$. Prior to this lowest point, Malaysia trade balance (InTB) was on an increasing trend since the early year 2009 which is contributed by large trade surplus amidst the ongoing financial crisis in US (Bank Negara Malaysia, 2009). The 10-year maturity rate of Malaysian Government Securities (MY10) also showed a declining trend during the $1^{\text {st }}$ quarter of 2009 which is caused by the action of Bank Negara Malaysia to reduce its overnight policy rate as a way to reduce Malaysia's exposure to the US financial crisis (Bank Negara Malaysia, 2009). Between 2008 and 2018, Malaysia's foreign bondholding reached a peak of 10.79 percent in July 2014. This was contributed by improving global outlook in 2014 and also the healthy performance of the Malaysian economy which contributed to the increase of foreign bondholding in Malaysia (Bank Negara Malaysia, 2014). Leading up to this point in July, 2014 the InTB was on a declining trend which was contributed by declining trade surplus caused by lower global crude oil prices which has negative affected the level of exports during the period (Bank Negara Malaysia, 2014).

Based on Figure 4, the foreign bondholding in Malaysia reached its lowest point on March, 2009 at $8.89 \%$. Prior to this lowest point the US Federal fund rate (USFS) was on increasing trend which was caused by the Federal Reserve decision to maintain the target of the Federal Fund Rate at $0 \%$ to $0.25 \%$. This target range is set to stimulate the US economy in the aftermath of the financial crisis (Board of Governors of the Federal Reserve System, 2009). As for the US total assets (InUSTA) leading up to the point in March, 2009 the InUSTA showed an increasing trend where the US continued to implement their unconventional monetary policy during the zero bound period by purchasing securities to stimulate their economy 
(Board of Governors of the Federal Reserve System, 2009). Based on Figure 4, from 2008 to 2018 , foreign bondholding in Malaysia hit a peak of 10.79 percent in July of 2014. The Federal Reserve's commitment to maintaining its unconventional monetary policy to give monetary stimulus in the United States' economy has led to a downward trend in the US Federal Funds rate, which also explains the steady trend of US total assets prior to July, 2014 (Board of Governors of the Federal Reserve System, 2014).

Figure 3: Trends of InFHOMGS, InCPI, InIPI, InTB and MY10 (Domestic Variables)

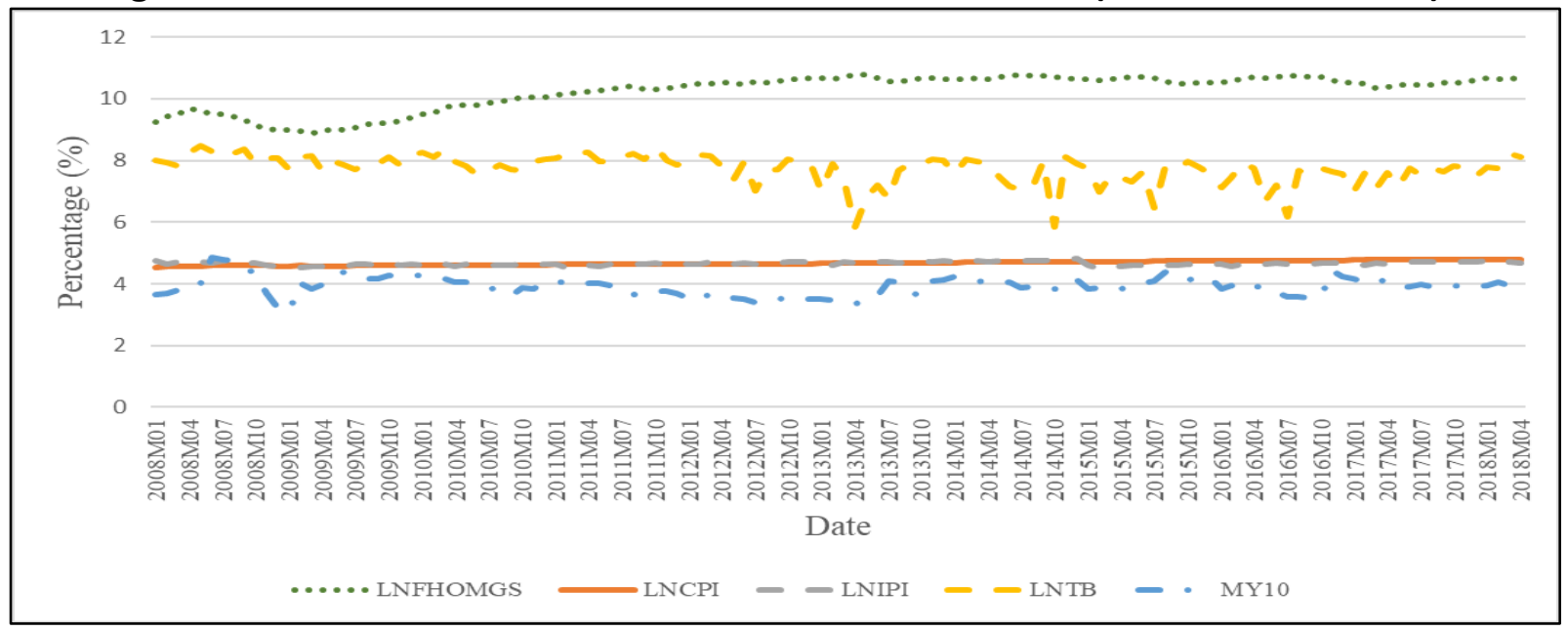

Sources: Bank Negara Malaysia and International Monetary Fund

Figure 4: Trends of InFHOMGS, InUSTA and USFS (External Variables)

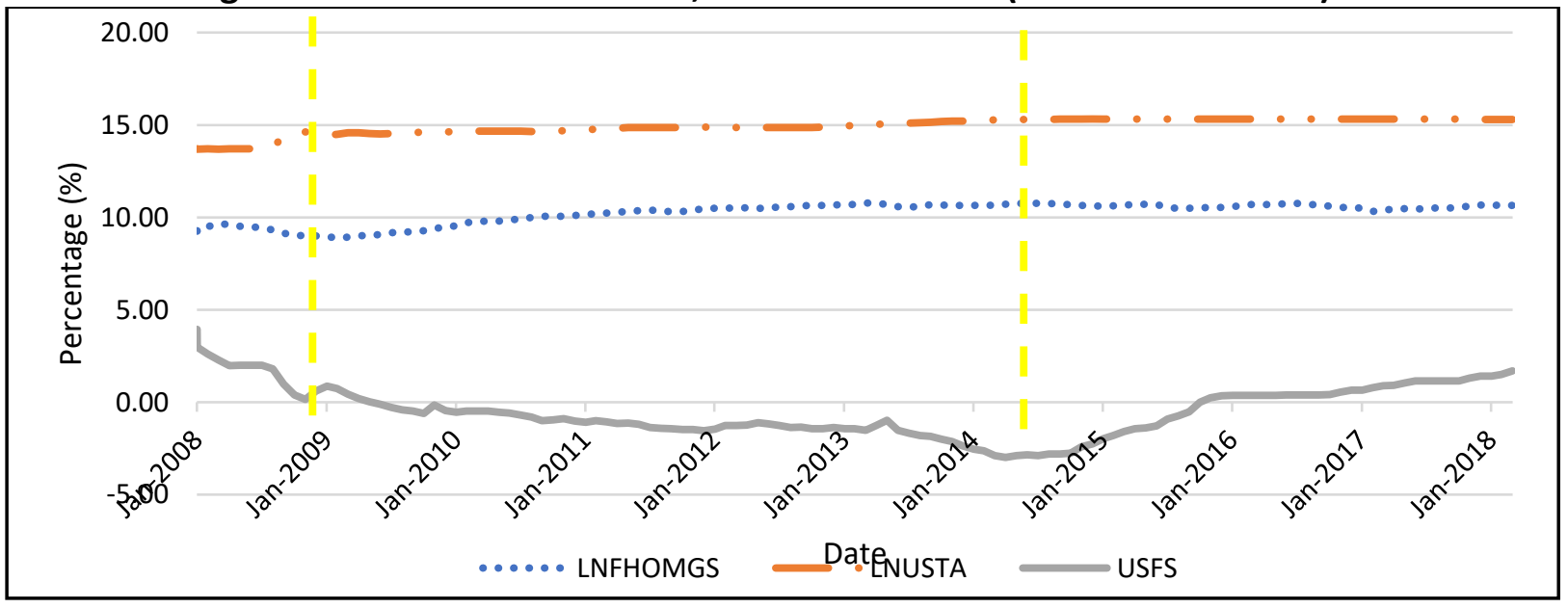

Sources: Bank Negara Malaysia and Federal Reserve of Bank St. Louis

\section{Lag Order Selection Results}

Tables 1 and 2 show the optimal lags that are selected by AIC. The optimal lags for Models 1 and 2 are 6 and 5 respectively. Hence, this study estimates Model 1 (with the US total assets) using lag=6 with the ARDL specification of $(2,1,4,2,1,6)$ and Model 2 (with the US Federal fund rate) using lag=5 with the ARDL specification of $(4,1,5,4,3,4)$. 
Table 1: Model 1's Lag Length Determination

\begin{tabular}{c|c}
\hline No of Lags & AIC \\
\hline Zero & -3.629393 \\
1 & -16.70259 \\
2 & -17.09444 \\
3 & -17.11448 \\
4 & -17.17253 \\
5 & -17.35008 \\
6 & $-17.49062^{*}$ \\
\hline
\end{tabular}

Note: * optimal lag selected by AIC

Table 2: Model 2's Lag Length Determination

\begin{tabular}{c|c}
\hline No of Lags & AIC \\
\hline Zero & -0.314703 \\
1 & -14.02788 \\
2 & -14.29507 \\
3 & -14.28988 \\
4 & -14.35034 \\
5 & $-14.55485^{*}$ \\
\hline
\end{tabular}

Note: * optimal lag selected by AIC

\section{Stationarity Test Results}

The stationarity tests will be estimated in this research using the Augmented Dickey Fuller (ADF) and Phillip-Perron (PP) tests. ADF results in Table 3 demonstrate that only the Malaysian trade balance (InTB) and the 10-year maturity rate of Malaysian government securities (MY10) are significant at $1 \%$ level when the intercept is taken into consideration. Only the Malaysian price level (InCPI), InTB, and MY10 are significant at a 5\%, 1\%, and 5\% significance level when trend and intercept are considered. However, when the trend and intercept are removed, none of the variables are significant at any level. After first differencing, when intercept, trend \& intercept and none are included all the variables are significant at $1 \%$ significance level.

Table 4 demonstrates that when the intercept is taken into account, only InIPI, InTB, MY10, InUSTA, USFS are significant at the $1 \%, 1 \%, 1 \%, 5 \%$, and $10 \%$ significance levels, respectively. Whereas when trend \& intercept is included, the results are similar with when intercept is included except InUSTA and USFS are not significant anymore. It is only the USFS that is significant when trend and intercept are excluded. After first differencing, when intercept, trend \& intercept and none are included all the variables are significant at $1 \%$ significance level.

Looking at the results in Tables 3 and 4, it is apparent that the variables are stationary at different order of integration. Hence, the estimation will proceed to Autoregressive Distributed Lag (ARDL) approach to cointegration for efficient estimation (Nkoro \& Uko , 2016). 
INTERNATIONAL JOURNAL OF ACADEMIC RESEARCH IN BUSINESS AND SOCIAL SCIENCES Vol. 11, No. 12, 2021, E-ISSN: 2222-6990 @ 2021 HRMARS

Table 3: ADF Results

\begin{tabular}{|c|c|c|c|c|c|c|}
\hline Variables & $\begin{array}{c}\text { With } \\
\text { Intercept }\end{array}$ & $\begin{array}{l}\text { With Trend } \\
\text { \& Intercept }\end{array}$ & $\begin{array}{c}\text { Without } \\
\text { Trend \& } \\
\text { Intercept }\end{array}$ & $\begin{array}{c}\text { With } \\
\text { Intercept }\end{array}$ & $\begin{array}{l}\text { With Trend } \\
\text { \& Intercept }\end{array}$ & $\begin{array}{l}\text { Without } \\
\text { Trend \& } \\
\text { Intercept }\end{array}$ \\
\hline \multicolumn{4}{|c|}{ Level } & \multicolumn{3}{|c|}{ First Difference } \\
\hline & & & & - & - & - \\
\hline \multirow[t]{2}{*}{ InFHOMGS } & $-1.2354(1)$ & $-1.2467(1)$ & $1.0045(1)$ & $7.3231(0)^{* * *}$ & $7.3191(0)^{* * *}$ & $7.2453(0)^{* * *}$ \\
\hline & & - & & - & - & - \\
\hline \multirow[t]{2}{*}{$\operatorname{lnCPI}$} & $-0.3941(4)$ & $3.7022(4)^{* *}$ & $3.0831(4)$ & $5.8363(3)^{* * *}$ & $5.8107(3)^{* * *}$ & $4.9371(2)^{* * *}$ \\
\hline & & & & - & - & - \\
\hline \multirow[t]{2}{*}{ InIPI } & $-1.9854(12)$ & $-2.1622(12)$ & $0.6503(12)$ & $4.0083(11)^{* * *}$ & $3.8948(11)^{* *}$ & $4.0048(11)^{* * *}$ \\
\hline & - & - & & - & - & - \\
\hline \multirow[t]{2}{*}{$\ln T B$} & $4.2303(1)^{* * *}$ & $4.9384(1)^{* * *}$ & $-0.3403(3)$ & $6.3258(7)^{* * *}$ & $5.7745(10)^{* * *}$ & $6.3493(7)^{* * *}$ \\
\hline & - & - & & - & - & - \\
\hline \multirow[t]{2}{*}{ MY10 } & $3.8899(0)^{* * *}$ & $3.8929(0)^{* *}$ & $-0.5088(7)$ & $10.3524(0)^{* * *}$ & $10.3076(0)^{* * *}$ & $10.3925(0)^{* * *}$ \\
\hline & & & & & - & - \\
\hline \multirow[t]{2}{*}{ InUSTA } & $-2.2420(10)$ & $-0.8534(11)$ & $1.3347(11)$ & $-2.8170(10) *$ & $5.7613(9)^{* * *}$ & $2.4874(10)^{* *}$ \\
\hline & & & & & - & - \\
\hline USFS & $-1.2973(3)$ & $-1.5259(1)$ & $-1.1807(3)$ & $-3.4838(4) * *$ & $6.3307(2)^{* * *}$ & $3.5293(4)^{* * *}$ \\
\hline
\end{tabular}

Note: $*, * *$ and $* * *$ indicate the level of significance at $10 \%, 5 \%$ and $1 \%$ respectively.

Table 4: PP Results

\begin{tabular}{|c|c|c|c|c|c|c|}
\hline Variables & $\begin{array}{c}\text { With } \\
\text { Intercept }\end{array}$ & $\begin{array}{l}\text { With Trend } \\
\text { \& Intercept }\end{array}$ & $\begin{array}{l}\text { Without } \\
\text { Trend \& } \\
\text { Intercept }\end{array}$ & With Intercept & $\begin{array}{l}\text { With Trend \& } \\
\text { Intercept }\end{array}$ & $\begin{array}{l}\text { Without Trend } \\
\text { \& Intercept }\end{array}$ \\
\hline \multicolumn{4}{|c|}{ Level } & \multicolumn{3}{|c|}{ First Difference } \\
\hline InFHOMGS & $-1.6137(6)$ & $-1.3410(6)$ & $1.2808(6)$ & $-7.4655(6) * * *$ & $-7.4698(6)^{* * *}$ & $-7.3952(6)^{* * *}$ \\
\hline $\operatorname{lnCPI}$ & $-0.6735(3)$ & $-2.7437(0)$ & $3.5803(3)$ & $-6.8836(7)^{* * *}$ & $-6.8493(7)^{* * *}$ & $-6.7518(1)^{* * *}$ \\
\hline & - & - & & & & \\
\hline InIPI & $\begin{array}{c}5.4344(4)^{* * *} \\
-\end{array}$ & $\begin{array}{c}5.7560(3)^{* * *} \\
-\end{array}$ & $-0.4227(62)$ & $-27.8906(23)^{* * *}$ & $27.7863(24)^{* * *}$ & $\begin{array}{c}28.0101(23)^{* * *} \\
-\end{array}$ \\
\hline $\ln T B$ & $\begin{array}{c}7.9615(7)^{* * *} \\
-\end{array}$ & $\begin{array}{c}8.7262(5)^{* * *} \\
-\end{array}$ & $-0.0741(10)$ & $-34.9398(15)^{* * *}$ & $35.7111(15)^{* * *}$ & $35.1922(15)^{* * *}$ \\
\hline MY10 & $\begin{array}{c}4.0993(1)^{* * *} \\
-\end{array}$ & $4.1032(1)^{* * *}$ & $0.1078(8)$ & $-11.1156(9)^{* * *}$ & $-11.0446(9)^{* * *}$ & $-11.1868(9)^{* * *}$ \\
\hline InUSTA & $3.4610(11)^{* *}$ & $-2.3481(10)$ & $\begin{array}{c}1.9532(4) \\
-\end{array}$ & $-5.8173(31)^{* * *}$ & $-6.4278(64)^{* * *}$ & $-6.0258(23)^{* * *}$ \\
\hline USFS & $-2.7979(6)^{*}$ & $-3.0048(0)$ & $2.4273(6)^{* *}$ & $-7.6220(3) * * *$ & $-8.4514(9)^{* * *}$ & $-7.6794(3)^{* * *}$ \\
\hline
\end{tabular}

Note: $*, * *$ and $* * *$ indicate the level of significance at $10 \%, 5 \%$ and $1 \%$ respectively.

\section{Autocorrelation Test Results}

In Table 5, $\mathrm{H}_{0}$ of no autocorrelation is not rejected for Model 1 with US total assets (InUSTA) as the prob. of Chi Square is $0.8353>0.05$. As the prob. of Chi Square is $0.5583>0.05, \mathrm{H}_{0}$ of no autocorrelation is also not rejected for Model 2 with US Federal fund rate (USFS). As a result, there is no autocorrelation in both models. 
Table 5: Autocorrelation Results

\begin{tabular}{|c|c|c|c|}
\hline Models & $\begin{array}{c}\text { F- } \\
\text { Statistics }\end{array}$ & $\begin{array}{c}\text { Prob. Chi } \\
\text { Square }\end{array}$ & Results \\
\hline 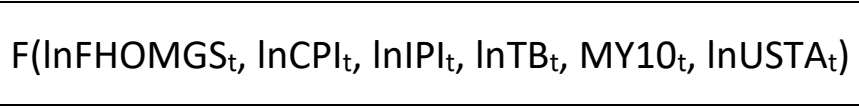 & 0.3676 & 0.8353 & $\begin{array}{l}\mathrm{H}_{0} \text { cannot } \\
\text { be rejected }\end{array}$ \\
\hline $\mathrm{F}\left(\operatorname{InFHOMGS} \mathrm{S}_{\mathrm{t}}, \operatorname{lnCPI} \mathrm{t}, \operatorname{InIPI} \mathrm{t}, \operatorname{InTB} \mathrm{t}, \mathrm{MY} 10_{\mathrm{t}}, \mathrm{USFS}_{\mathrm{t}}\right)$ & 0.6036 & 0.5583 & $\begin{array}{l}\mathrm{H}_{0} \text { cannot } \\
\text { be rejected }\end{array}$ \\
\hline
\end{tabular}

\section{Parameter Stability Results}

In Figures 5 and 6 , the stability of the models are tested through the CUSUM and CUSUM Sum of Square tests. Both cumulative sum and cumulative sum of squares are generally within the $5 \%$ significance lines, indicating that the parameter and residual variance are stable in both models.

Figure 5: Parameter Stability Results for Model 1 with US Total Assets

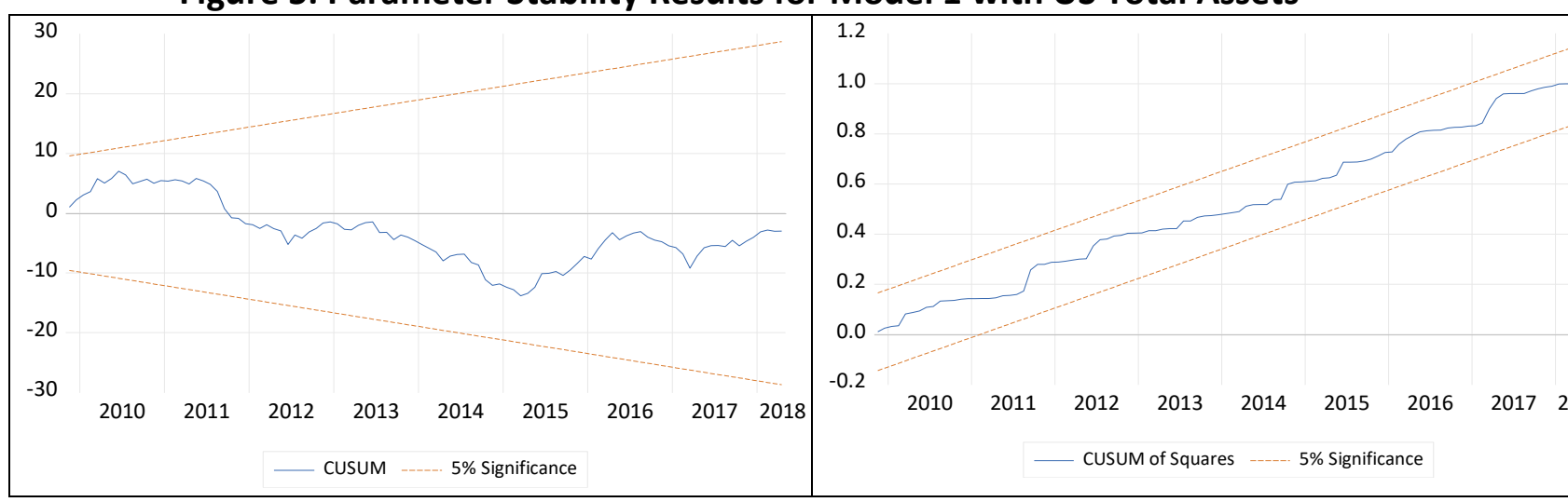

Figure 6: Parameter Stability Results for Model 2 with US Federal fund rate

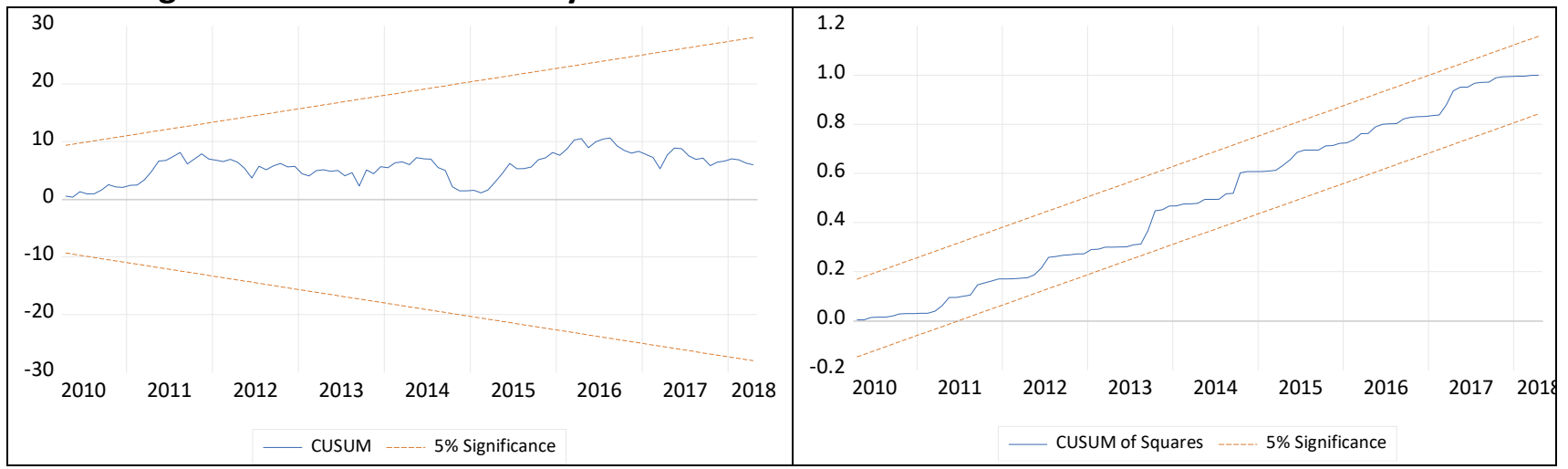

\section{Bound Test Results}

In Table 6, Model 1 with US total assets (InUSTA) shows that there is a cointegration exist in the model at $1 \%$ significance level which clearly indicates that the F-statistic generated at 7.4040 is greater than the upper bound critical values of 4.15. As with Model 2, the F-statistic is 3.5948 and greater than the upper bound critical value of 3.38 at a $5 \%$ significance level, indicating the presence of cointegration in the model. 
Table 6: Bound Test for Cointegration

\begin{tabular}{|c|c|c|c|c|}
\hline \multirow[t]{2}{*}{ Models } & \multirow[t]{2}{*}{ F-statistics } & \multirow[t]{2}{*}{$\begin{array}{c}\text { Significance } \\
\text { Level }\end{array}$} & \multicolumn{2}{|c|}{ Critical values } \\
\hline & & & $I(0)$ & $/(1)$ \\
\hline \multirow{4}{*}{ 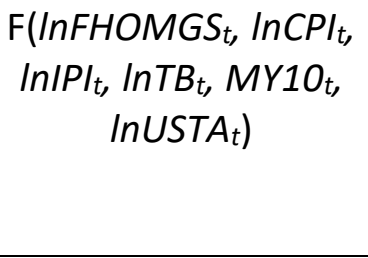 } & $7.4040 * * *$ & $10 \%$ & 2.08 & 3.00 \\
\hline & & $5 \%$ & 2.39 & 3.38 \\
\hline & & $2.5 \%$ & 2.70 & 3.73 \\
\hline & & $1 \%$ & 3.06 & 4.15 \\
\hline \multirow{4}{*}{ 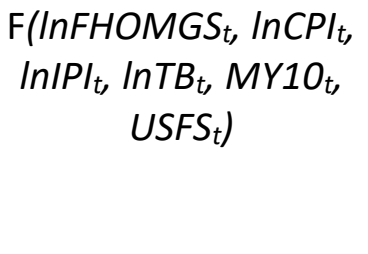 } & $3.5948 * *$ & $10 \%$ & 2.08 & 3.00 \\
\hline & & $5 \%$ & 2.39 & 3.38 \\
\hline & & $2.5 \%$ & 2.70 & 3.73 \\
\hline & & $1 \%$ & 3.06 & 4.15 \\
\hline
\end{tabular}

Note: ${ }^{* *}$ and $* * *$ denotes level of significance at $5 \%$ and at $1 \%$ respectively.

\section{ECM Results}

In Table 7, the coefficient of the ECM for Model 1 with InUSTA is -0.086846 , which is negative and highly significant at the $1 \%$ level. As for Model 2 with USFS, the coefficient of the ECM is -0.088600 and highly significant at $1 \%$ level. Based on these results, the variables in Model 1 and Model 2, are confirmed to have a long run relationship.

Table 7: ECM Results

\begin{tabular}{|c|c|c|c|c|}
\hline \multirow[b]{2}{*}{ Models } & \multicolumn{4}{|c|}{ Variable: CointEq(-1)* } \\
\hline & Coefficients & $\begin{array}{l}\text { Standard } \\
\text { Errors }\end{array}$ & T-Statistics & P-values \\
\hline 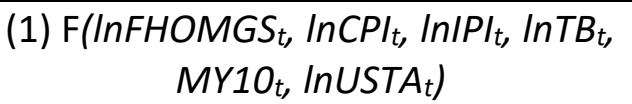 & -0.086846 & 0.011723 & -7.407872 & $0.0000 * * *$ \\
\hline 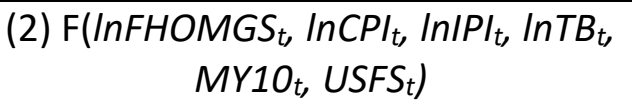 & -0.088600 & 0.017140 & -5.169162 & $0.0000 * * *$ \\
\hline
\end{tabular}

Note: ${ }^{* * *}$ denotes level of significance at $1 \%$.

\section{Long Run Coefficients Results}

Based on Table 8, for Model 1 with US total assets, the results show that all of the variables are significant. The InCPI, which is significant at the $5 \%$ level, demonstrates a negative relationship with the dependent variable, with a $1 \%$ rise in the Malaysian CPI resulting in a $3.75 \%$ decline in foreign bondholding in Malaysia. The positive association between the dependent variable and InIPI, which is significant at the $1 \%$ level, shows that a $1 \%$ increase in the Malaysia industrial production index will result in a 3.36\% increase in foreign bondholding in Malaysia. In contrast, InTB reveals a positive significant association, with a $1 \%$ increase in Malaysia's trade balance causing a $0.44 \%$ increase in foreign bondholding in Malaysia. MY10 has a negative and significant association with the dependent variable, with a 1 percent increase in the 10-year maturity rate of Malaysia government securities causing a 0.85 percent decrease in foreign bondholding in Malaysia. Finally, there is a positive significant relationship between the dependent variable and InUSTA, with a $1 \%$ increase in US total assets causing a 1.33\% increase in foreign bondholding in Malaysia. The following is the long run model that is obtained from Table 8 : 


\section{$\ln F H O M G S=-7.5996-3.7465 \ln C P I^{* *}+3.3565 \ln I P I^{* * *}+0.4410 \ln T B^{* *}-$ $0.8452 M Y 10^{* * *}+1.3294 \ln U S T A^{* * *}$}

(6)

Based on Table 9, for Model 2 with US Federal fund rate, the results show that all of the variables are significant except for InTB. In contrast with the first model abovementioned, the InCPI exhibit a positive relationship with the dependent variable where $1 \%$ increase in Malaysia price level will cause the foreign bondholding in Malaysia to also increase by $3.74 \%$. As for InIPI, a 1\% increase in Malaysia industrial production index will cause the foreign bondholding in Malaysia to also increase by $2.15 \%$. The MY10, on the other hand, demonstrates an inverse link in which an increase in the 10-year maturity rate of Malaysian government securities causes foreign bondholding in Malaysia to fall by one percent. Finally, the USFS has an inverse association with the dependent variable, with a $1 \%$ increase in the US Federal Fund rate causing a $0.13 \%$ decrease in foreign bondholding in Malaysia. As a result of Table 8 , the long run model is shown below:

$\ln F H O M G S=-14.2033+3.7372 \ln C P I^{* * *}+2.1533 \ln I P I^{*}+0.1016 \ln T B-$ $1.0004 M_{Y 10^{* * *}}-0.1253 U_{S F S}^{* * *}$

(7)

Table 8: Long Run Results for Model 1 (US total assets)

\begin{tabular}{ccccc}
\hline Variables & Coefficients & $\begin{array}{c}\text { Standard } \\
\text { Errors }\end{array}$ & T-Statistics & P-values \\
\hline InCPI & -3.746546 & 1.765738 & -2.121801 & 0.0363 \\
InIPI & 3.356496 & 0.948866 & 3.537375 & 0.0006 \\
InTB & 0.441002 & 0.175821 & 2.508242 & 0.0137 \\
MY10 & -0.845156 & 0.199500 & -4.236369 & 0.0000 \\
InUSTA & 1.329427 & 0.264439 & 5.027342 & 0.0000 \\
C & -7.599601 & 6.050374 & -1.256055 & 0.2120 \\
\hline
\end{tabular}

Note: $* * *$ and $* * *$ denote the level of significance at $10 \%, 5 \%$ and $1 \%$ respectively.

Table 9: Long Run Results for Model 2 (US Federal fund rate)

\begin{tabular}{ccccc}
\hline Variables & Coefficients & $\begin{array}{c}\text { Standard } \\
\text { Errors }\end{array}$ & T-Statistics & P-values \\
\hline InCPI & 3.737272 & 1.377238 & 2.713599 & 0.0079 \\
InIPI & 2.153272 & 1.130663 & 1.904433 & 0.0598 \\
InTB & 0.101647 & 0.202019 & 0.503157 & 0.6160 \\
MY10 & -1.000441 & 0.240981 & -4.151535 & 0.0001 \\
USFS & -0.125258 & 0.040031 & -3.128988 & 0.0023 \\
C & -14.20329 & 7.074173 & -2.007767 & 0.0474 \\
\hline
\end{tabular}

Note: ${ }^{* * *}$ and ${ }^{* * *}$ denote the level of significance at $10 \%, 5 \%$ and $1 \%$ respectively

\section{Conclusion}

\section{Discussion}

Based on Model 1 with US total assets, the result revealed that all the independent variables are significant in the model. The Malaysian price level has a negative relationship with foreign bondholding in Malaysia. This suggests that as Malaysia's price level rises, foreign bondholding in the country declines, which is consistent with the Burger et al. study (2015). They discovered that as inflation volatility falls, capital inflows into emerging market countries 
increase significantly. Reduced inflation volatility is related with reduced reinvestment risk, which encourages capital inflow into emerging market economies (Burger et al., 2015). The empirical findings also show that the InIPI has a positive association with foreign bondholding in Malaysia, implying that as the industrial production index rises, so will the amount of foreign bondholding in Malaysia. This finding is in line with a previous study by Fratzscher (2012), who claimed that countries with strong macroeconomic fundamentals, such as stable GDP growth, will be able to attract more capital into their markets.

In terms of InTB, the result of equation (6) reveals that Malaysia's trade balance has a positive and significant association with foreign bondholding. This means that if Malaysia's trade balance improves, the country's foreign bond holdings will rise. Burger et al. (2015) supported this view, arguing that countries with a positive current account balance will be able to attract funds, and further suggested that this allocation of capital inflow will mostly originate from advanced countries such as the US. For MY10, the result of equation (6) indicates an inverse association between the 10-year maturity rate of Malaysian Government Securities and foreign bondholding in Malaysia. This suggests that an increase in the MY10 will result in a decrease in foreign bondholding in Malaysia. This finding is in line with a study by Bhattarai, Chatterjee, and Park (2018), which claimed that during the implementation of US unconventional monetary policy, the long-term yield in US will decrease hence US investors will seek fund in emerging market economies which causes the foreign bondholding to increase in the emerging markets. As a result of the increased demand in the market for high yield assets, asset prices in emerging markets will rise, putting downward pressure on the country's long-term yield. For Model 1, the InUSTA result from equation (6) reveals a positive link between US total assets and foreign bondholding in Malaysia, implying that an increase in US total assets will also cause an increase in foreign bondholding in Malaysia. This finding is consistent with Bhattarai, Chatterjee, and Park's (2018) study, which indicated that when the US purchases assets in large quantities in the market, capital flows into emerging market economies.

Model 2, the long run model generated from equation (7), shows that the sign of Malaysia price level coefficient is inconsistent with previous findings, such as a study by Burger et al. (2015), which found that when inflation volatility in emerging market economies is low, capital inflow into the country increases. The result provided for InIPI shows that the Malaysia industrial production index has a positive relationship with foreign bondholding in Malaysia, as shown by equation (7). This result is in line with Fratzscher (2012). The result of MY10 shows that, based on the sign of (-) generated in equation (7), this finding is consistent with a study by Bhattarai, Chatterjee, and Park (2018), which supports the notion that the country's long-term yield will fall when capital inflow increases due to the implementation of US unconventional monetary policy. As for USFS, the US Federal fund rate has a negative association with foreign bondholding in Malaysia, with a fall in the US Federal fund rate causing an increase in foreign bondholding in Malaysia. This finding is consistent with the findings of a previous study by Kiendrebeogo (2016), who discovered that the prolonged duration of the US Federal Funds rate at zero bound level encourages capital inflows to emerging market economies. Overall, based on the explanation above, Model 1 is a better model to explain the influence of the US unconventional monetary policy on foreign bondholding in Malaysia because all of the variables are significant and all of the indications are consistent with the majority of earlier studies. 


\section{Policy Implications}

Both the pull (domestic) factors and the push (external) factors influence Malaysia's level of foreign bondholding. As the study employed Model 1 as the best model, the negative relationship between Malaysia price level and foreign bondholding in Malaysia in equation (6) showed that there is a need for the Malaysian government to control the price level in the country. By ensuring the price level to be stable and low, such policy will attract more bondholding by non-residents into Malaysia. As of late, based on a report by Bank Negara Malaysia (2017), the inflation level in Malaysia in the year 2017 was 3.7\% which saw an increase from $2.1 \%$ recorded in the year 2016. This steady increase in inflation was largely contributed by the higher domestic fuel prices (Bank Negara Malaysia, 2017). Hence, with these developments, the Malaysian government has implemented a policy to control inflationary pressure by improving the country's labour productivity (Bank Negara Malaysia, 2017).

As for Malaysia industrial production index, which exhibits a positive relationship with foreign bondholding in Malaysia derived from equation (6), the findings clearly indicate that the Malaysian government need to ensure steady growth in the country's economy to attract more non-residents to purchase government bonds in Malaysia. To ensure such policy is pursued, the Malaysian government has outlined its plan in the 2018 Budget Plan to further retain the country's steady growth Gross Domestic Product (GDP) through infrastructure projects that have large multiplier effects on the economy (Bank Negara Malaysia, 2017). Hence, such a plan should be continued to ensure the steady growth of Malaysia's GDP.

Next, result for Malaysia trade balance which clearly indicated that it has a positive relationship with foreign bondholding in Malaysia as derived from equation (6), shows that the Malaysian government needs to ensure that the trade balance of the country continues to increase to support capital inflow into the country through foreign bondholding. The report by Bank Negara in 2017 stated that the trade balance in Malaysia improved from RM88.1 billion in the year 2016 to RM97.2 billion in the year 2017 (Bank Negara Malaysia, 2017). The report also stated that this was primarily contributed by a higher surplus in Electrical \& Electronic (E\&E) and commodities exports. Hence, the Malaysian government should focus on these two industries to retain the positive growth in the country trade balance through improved infrastructures and increased investment in the country E\&E sub-sectors and the commodities downstream sector.

The findings from equation (6) further reveal that the 10-year maturity rate of the Malaysian government securities has a negative relationship with foreign bondholding in Malaysia. According to the same annual report by Bank Negara Malaysia in 2017, despite the decline in yield for Malaysian Government Securities across all maturities in 2017, the demand for the country's government securities is still high, especially among non-residents (Bank Negara Malaysia, 2017). This demand was primarily contributed by Malaysia's strong macroeconomic fundamentals in 2017 and lower volatility in the global financial market (Bank Negara Malaysia, 2017). Hence, to ensure that a lower government securities yield is still able to attract foreign bondholding in the country, the Malaysian government has to keep pursuing a policy that can sustain the country strong macroeconomic fundamentals such as controlled inflation, steady GDP growth and positive trade balance.

The result for US total assets with foreign bondholding in Malaysia in equation (6) reveals a positive relationship between the two variables. This indicates that when the US increase their purchase of securities in the market through its unconventional monetary policy, the foreign bondholding in Malaysia will increase. Thus, this indicates that Malaysia 
will be getting a direct effect if the US pursue a reversal of its unconventional monetary policy. According to Bank Negara Malaysia (2017), the Federal Reserve has started reducing the US balance sheet starting in October 2017, which means that the US will reduce its purchase of securities in the market. Hence, to mitigate against this reversal in US unconventional monetary policy, Malaysia has to ensure that its macroeconomic fundamentals are strong. This notion is supported by a finding by Kiendrebeogo (2016), which stated that emerging countries with stronger fiscal and current account positions will mitigate reversal in capital flows due to the monetary policy reversal in the US.

Lastly, is the result for US Federal fund rate in equation (7) reveals that the variable has a negative and significant relationship with the foreign bondholding in Malaysia. This finding reveals that the foreign bondholding in Malaysia will be directly influenced by the US Federal fund rate. If the US starts to ease its unconventional monetary policy by increasing its federal fund rate, this will cause a fall in the foreign bondholding in Malaysia. Overall, this study finds both push and pull factors are important to explain the level of foreign bondholding in Malaysia.

\section{Acknowledgement}

This research is being carried out as part of the Fundamental Research Grant Scheme (FRGS) of the Malaysian Ministry of Education under the project number FRG0458-2017.

\section{References}

Abdullah, A. S., \& Razali, N. M. (2017). Publication. Retrieved from Bank Negara Malaysia: https://www.bnm.gov.my/files/publication/qb/2017/Q2/p5_ba1.pdf

Bank Negara Malaysia. (2009). Bank Negara Annual Report 2009. Kuala Lumpur: Bank Negara Malaysia.

Bank Negara Malaysia. (2014). Bank Negara Malaysia Annual Report 2014. Kuala Lumpur: Bank Negara Malaysia.

Bank Negara Malaysia. (2017). Bank Negara Annual Report 2017. Kuala Lumpur: Bank Negara Malaysia.

Bhattarai, S., Chatterjee, A., \& Park, W. Y. (2018). Effects of US quantitative easing on emerging market economies. ADBI Working Papers No.803.

Bhattarai, S., \& Neely, C. (2016). A survey of the empirical literature on U.S. unconventional monetary policy. Federal Reserve Bank of St. Louis Working Paper Series No.2016-21.

Board of Governors of the Federal Reserve System. (2014). 101st Annual Report. Washington DC: Board of Governors of the Federal Reserve System.

Board of Governors of the Federal Reserve System. (2009). 96th Annual Report. Washington DC: Board of Governors of the Federal Reserve System.

Burger, J. D., Sengupta, R., Warnock, F. E., \& Warnock, V. C. (2015). US investment in global bonds: as the Fed pushes, some EMEs pull. Economic Policy, 30(84), 729-766.

Cerutti, E., Claessens, S., \& Puy, D. (2017). Push factors and capital flows to emerging markets: why knowing your lender matters more than fundamentals. ADB Economics Working Paper Series No. 528.

Eichler, S., \& Plaga, T. (2017). The political determinants of bondholding. Journal of International Money and Finance, 73, 1-21.

Fratzscher, M. (2012). Capital flows, push versus pull factors and the global financial crisis. Journal of International Economics, 88(2), 341-356. 
Fratzscher, M., Lo Duca, M., \& Straub, R. (2018). On the international spillovers of US quantitative easing. The Economic Journal, 128(608), 330-377.

Koepke, R. (2018). Fed policy expectations and portfolio flows to emerging markets. Journal of International Financial Markets, Institutions \& Money, 55, 170-194.

Kiendrebeogo, Y. (2016). Unconventional monetary policy and capital flows. Economic Modelling, 54, 412-424.

Moore, J., Nam, S., Suh, M., \& Tepper, A. (2013). Estimating the impacts of U.S LSAPs on Emerging Market Economies' Local Currency Bond Markets. Federal Reserve Bank of New York Staff Reports, (595), 1-45.

Nkoro, E., \& Uko, K. (2016). Autoregressive Distributed Lag (ARDL) cointegration technique: application and interpretation. Journal of Statistical and Econometric Methods, 5(4), 6391.

Pesaran, M. H., Shin, Y., \& Smith, R. J. (2001). Bounds testing approaches to the analysis of level relationships. Journal of Applied Econometrics, 16(3), 289-326.

Punzi, M. T., \& Chantapacdepong, P. (2017). Spillover effects of unconventional monetary policy in Asia and the Pacific. Asian Development Bank Institute Working Paper Series No. 630.

Tillmann, P. (2016). Unconventional monetary policy and the spillovers to emerging markets. Journal of International Money and Finance, 66, 136-156

$\mathrm{Wu}$, J. C., \& Xia, F. D. (2016). Measuring the macroeconomic impact of monetary policy at the zero lower bound. Journal of Money, Credit and Banking, 48(2-3), 253-291. 